\title{
Directed Medical Role Play for Children: Review of the Teddy Bear Hospital implementations, objectives, and reported experiences
}

Reem Jazrawy ${ }^{1}$, Sharon Mascarenhas $\mathrm{MSc}^{2 *}$, Youness Zidoun $\mathrm{PhD}^{2}$, Nabil Zary MD, $\mathrm{PhD}^{2}$

1. GEMS Winchester, Dubai, United Arab Emirates

2. Institute for Excellence in Health Professions Education (ieHPE), Mohammed Bin Rashid University of Medicine and Health Sciences, Dubai, United Arab Emirates

*Corresponding author:

Sharon Mascarenhas, MSc

Institute for Excellence in Health Professions Education (ieHPE)

Mohammed Bin Rashid University of Medicine and Health Sciences (MBRU)

Dubai, United Arab Emirates

Email.Sharon.Mascarenhas@mbru.ac.ae 


\begin{abstract}
Background: Role-playing is often used as a pedagogical method for learning communication in medical education. Therefore, medical play using the Teddy Bear Hospital (TBH) is a concept that can quickly familiarize children with health care and help them develop positive experiences in these areas. This review aims to assess the strengths of TBH, as a form of directed medical role play, in improving health outcomes and well-being in children, along with implanting an awareness of preventive health care in young children.

Methods: For this scoping review, we examined the list of recommendations, including 11 studies from two databases, PubMed and Google Scholar. We incorporated pre/post quasi-experimental studies, ANOVA, qualitative research studies, systematic reviews, and control group studies that deliberately utilize the teddy bear hospital as an intervention.

Results: The results of individual studies were further categorized into three sections. The first being upon the analysis of 11 studies, the Teddy Bear Hospital was mainly conducted in Europe and Asia. It is evident that regardless of the different approaches and strategies used to implement the Teddy Bear Hospital, they all ultimately share the same intent: to raise health care awareness and alleviate young children's anxiety over medical treatment while focusing on the promotion of positive healthy lifestyle. All studies portray the teddy bear hospital as an intervention of medical roleplay which analyzed the children's feelings, behaviors, and health awareness after visiting the Teddy Bear Hospital.

Conclusion: The application of the teddy bear hospital has overwhelmingly positive results, with lower levels of anxiety and improved health knowledge. Its reported efficacy calls for future studies on aspects that lead to its efficacy and potential effectiveness.
\end{abstract}

Keywords: Role-play, medical roleplay, teddy bear hospital, teddy bear clinic. 


\section{Introduction}

Throughout the world, roleplaying is used as a teaching method that has been proven to create an inquiry-based learning environment. Studies have shown it to be highly effective in achieving key learning outcomes such as: affective, cognitive, and behavioral [1]: by putting students in the role of another person, they practice empathy and gain perspective. This can lead to a greater multitude of self-reflection and awareness on the part of the students. [2]

Roleplaying has been primarily used in educational settings that highlight the social dynamics of learning and promote collaboration among students [3]. Specific explorations have found that this technique helps get students to entirely surpass practical cognitive skills as well [4]. Research on roleplay at Birmingham university medical school concludes that medical play as a teaching strategy for children at this developmental age solidifies various events that young kids encounter and creates momentum as they venture into the next steps in their lives [5].

The phrase "directed medical role play" applies to a pretend play activity with children, generally involving the utility of a toy medical equipment in a playful, educational and inquiring way with the presence of a knowledgeable guardian [6]. This method has been proven to reduce children's anxiety and discomfort during any type of medical procedure. It also has an incredibly positive impact on parents during this journey as they can better understand the specifics of each procedure. Not only does such guidance put parents at ease, but it also radiates encouragement leading to a boost in the child's self-confidence to stimulate an optimistic escapade [6].

The teddy bear hospital is one of the many strategies used as a medical roleplay introduced by Santen and Feldman in 1994 aimed at children between the ages of 6 to 8 years [7]. It is usually recommended that children be taught not to be afraid of interacting with medical personnel, as this can lead to an unusual increase in medical errors, malpractice, and inaccurate diagnoses. Therefore, the teddy bear hospital serves as a strategy to not only reduce children's' constant discomfort with the healthcare system but also to encourage them and introduce them to medicine from a different perspective[8]. It is an innovation where children bring their teddy bears while visiting volunteers in simulated hospital environments, who take on the role of healthcare professionals. In this way, the children's fears of hospitalization are reduced, and their knowledge in healthcare is expanded.

In addition, hospitalization can be a traumatic life experience for a child. If a previous hospitalization with bad memories was traumatic, future hospitalizations could be expected to reinforce the trauma[9]. Fear for one's body, fear of being separated from what is known and familiar, physical pain, and lack of control over one's environment make a pediatric hospitalization an event that evokes only negative memories[10]. Apart from the fact that it helps them discard their fears[11], but it is known worldwide that the Teddy Bear Hospital concept increases familiarity with the hospital environment, promotes interest in the work of healthcare professionals[12] and helps promote medicine as a career option for inner-city children because this project encourages talented students to consider a career in medicine or 
one of the medical-related professions by fostering interest and providing support to become the future of medicine[13].

Events like the teddy bear hospital encourage children to take on the roles of healthcare professionals, acting out medical procedures and events on dolls, puppets, or soft toy animals using pretend toy doctor kits, a patient puppet, a doll sized MRI, or hospital bed. They often use this type of medical play to re-enact events they have experienced or yet to experience due to specific fears and phobias, which sets their expectations. This is also helpful for healthcare students as they practice their communication skills before delving into the real world of medicine.

This is pointed out by Jones (1980) in one of his articles, "for a simulation to take place, the participants must accept the duties and responsibilities of their roles and functions, and do the best they can in the situation in which they find themselves" and these roleplaying activities are prominent in Teddy Bear Hospital programs

This research paper targets the Teddy Bear Hospital as a strategy to implement a community innovation that helps children learn about medical procedures they may or may not encounter in the future in a fun and non-threatening environment and supports them by familiarizing them with health care professionals to ensure proper diagnosis and smooth recovery.

The objective of this literature review is to discuss:

- In which different countries was the Teddy Bear Hospital conducted?

- What were the objectives and approaches taken in conducting the Teddy Bear Hospital?

- What was the experience/outcome with the respective objectives and approaches taken in conducting the Teddy Bear Hospital?

\section{Methods}

\section{Search strategy}

After scouring PubMed and Google scholar to find out about the various aspects of the Teddy Bear hospital as an expression of medical roleplaying and its part in the development of our community[6]. We found a few research studies that show several ways to provide medical role play to both patients and medical professionals, a combination of keywords that were used as medical subheadings were (1): "medical role play", "teddy bear hospital" and "teddy bear clinic". (2).

\section{Study selection}

We culminated a total number of 49 results on PubMed. The results that were irrelevant to The Teddy Bear hospital or roleplaying were excluded and certain papers were excluded because they studied sick children in hospital, did not use teddy bear hospital, or their results 
were not consistent with the study objectives; therefore, we came to an overall result of 11 studies that will be further elaborated later in the research.

\section{Process for selection of relevant studies}
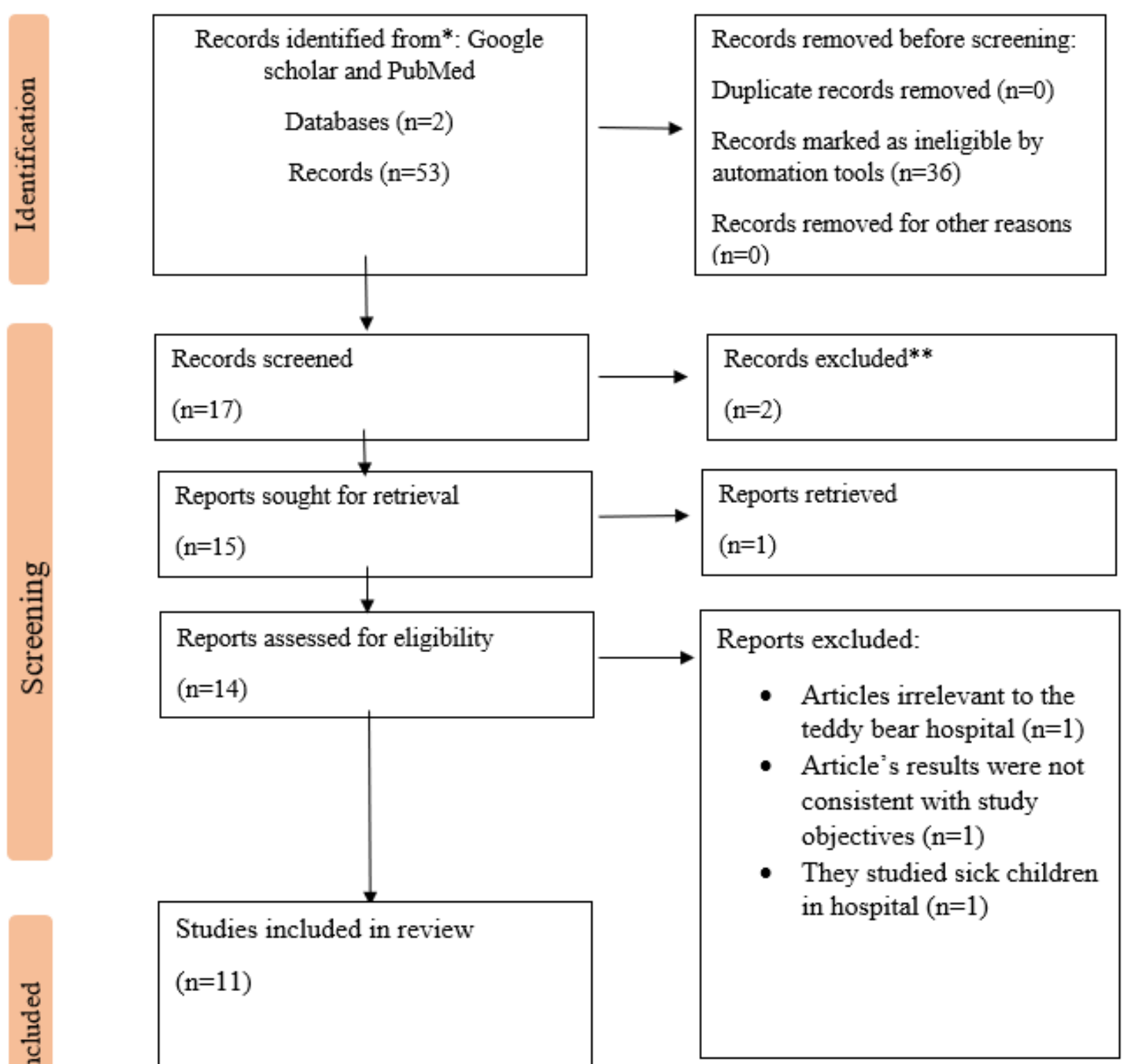

Figure 1: PRISMA of the process for selecting the relevant studies 


\section{Results}

As a result of our scoping review through the studies identified, we acknowledge and address the aim and objectives of our research paper based on the 11 research studies included in the review. We began by sieving out data on which countries conducted the Teddy Bear Hospital, gathered information on the Teddy bear hospital used as a strategy, and the experience and effectiveness of that strategy among children.

In which different countries was the Teddy Bear Hospital conducted?

Upon the analysis of 11 studies, the Teddy Bear Hospital was mainly conducted in Europe and Asia as displayed in Figure 2. Further analyzing it is observed that $18.2 \%$ of the events took place in Australia, $18.2 \%$ in Malaysia, $18.2 \%$ in Canada, $18.2 \%$ in Israel/Palestine, $9.1 \%$ in Norway, $9.1 \%$ in Germany, and $9.1 \%$ in the Netherlands as displayed in Figure 3.

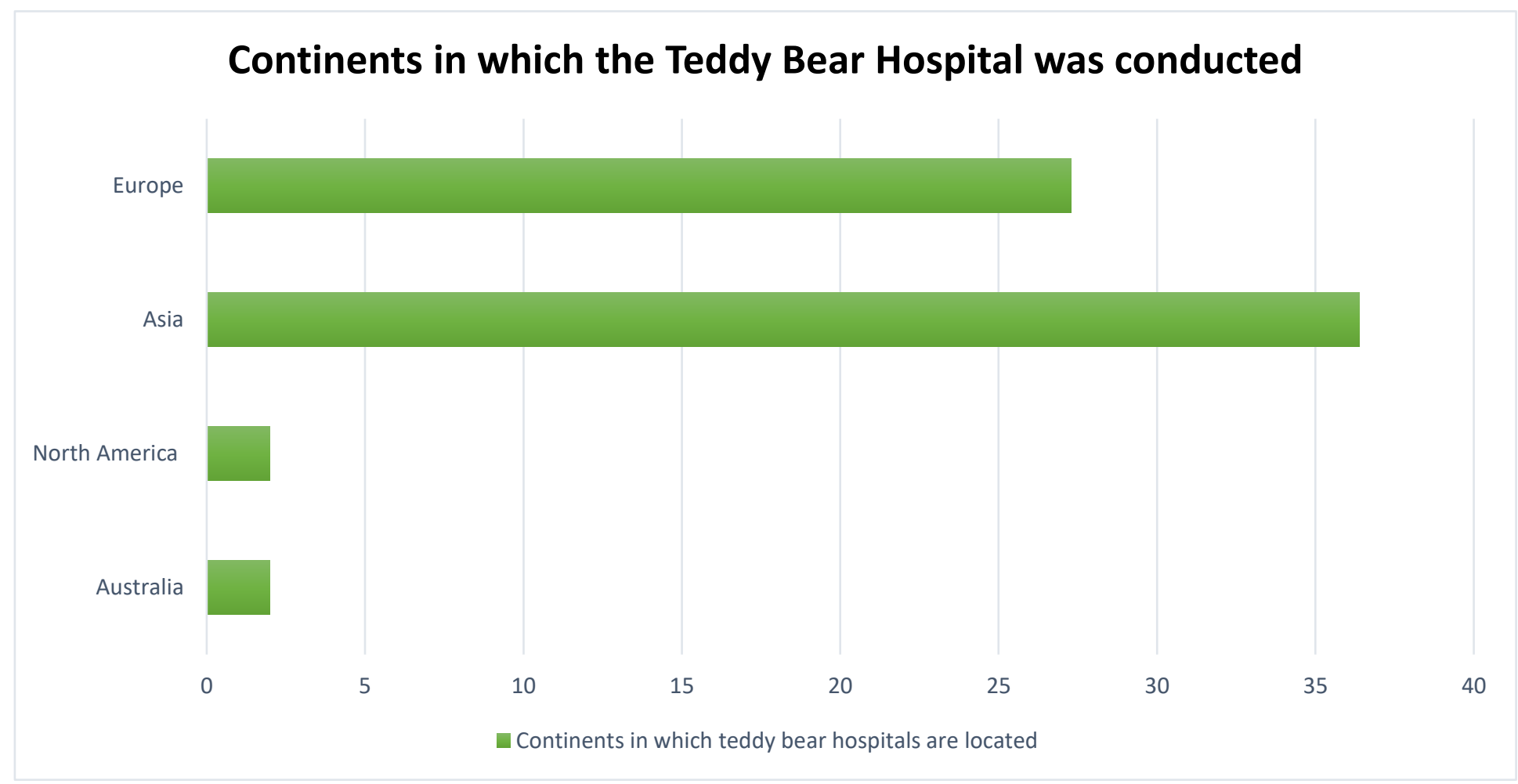

Figure 2: The continents in which the teddy bear hospital in the selected studies was conducted 


\section{Number of Teddy Bear Hospitals conducted in countries}

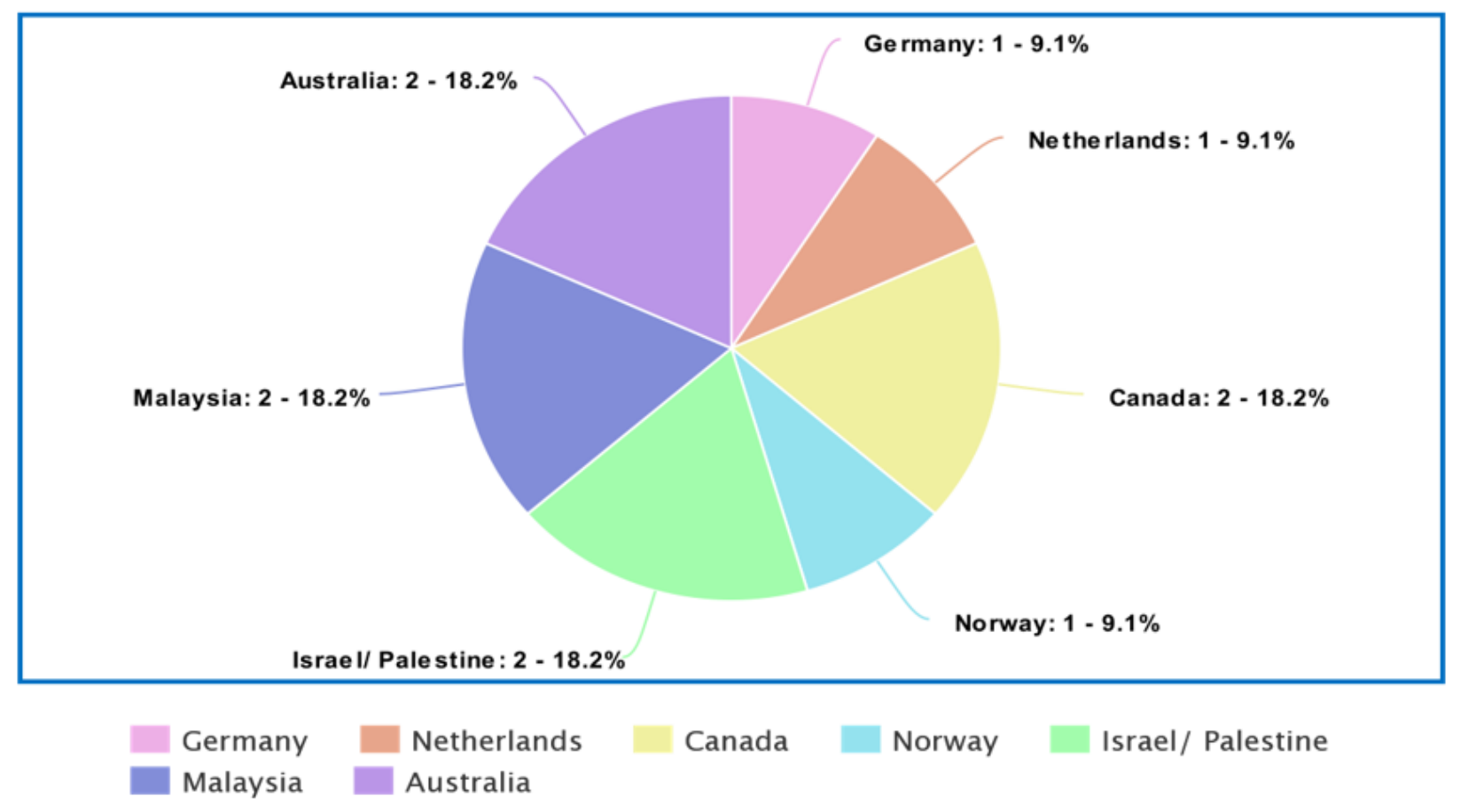

Figure 3: The number of Teddy Bear Hospitals conducted in countries

Table 1: Comprehensive overview of articles categorized into countries, years, study design, and findings.

\begin{tabular}{|l|l|l|l|l|l|}
\hline N. O & \multicolumn{1}{|c|}{ Source } & Countries & Years & Study design & \multicolumn{1}{|c|}{ Findings } \\
\hline 1 & $\begin{array}{l}\text { Does the 'Teddy } \\
\text { Bear Hospital' } \\
\text { enhance preschool } \\
\text { children's } \\
\text { knowledge? } \\
{[13]}\end{array}$ & Germany & 2013 & $\begin{array}{l}\text { Pre/post case } \\
\text { control, quasi- } \\
\text { experimental } \\
\text { design }\end{array}$ & $\begin{array}{l}\text { After the study was } \\
\text { conducted, the analysis } \\
\text { showed that children who } \\
\text { attended the teddy bear } \\
\text { hospital had significantly } \\
\text { better knowledge about their } \\
\text { anatomical structure, health, } \\
\text { and diseases than in the } \\
\text { control group. }\end{array}$ \\
\hline
\end{tabular}




\begin{tabular}{|c|c|c|c|c|c|}
\hline 2 & $\begin{array}{l}\text { The Teddy Bear } \\
\text { Hospital: How to } \\
\text { influence the } \\
\text { attitude of } \\
\text { kindergarten } \\
\text { children towards } \\
\text { doctors, hospitals } \\
\text { and falling ill? } \\
\text { [7] }\end{array}$ & Netherlands & 2018 & $\begin{array}{l}\text { ANOVA } \\
\text { (Analysis of } \\
\text { variance) }\end{array}$ & $\begin{array}{l}\text { Children have more positive } \\
\text { attitudes toward doctors, } \\
\text { illnesses, and hospitals. The } \\
\text { change in attitude toward } \\
\text { illness may be related to pre- } \\
\text { visit teaching. In contrast, } \\
\text { the change in attitude } \\
\text { toward doctors and hospitals } \\
\text { may be related to actual } \\
\text { visits to Teddy Bear } \\
\text { Hospital, suggesting a } \\
\text { positive role for real-life } \\
\text { learning in school. A change } \\
\text { in attitude could lead to a } \\
\text { positive attitude towards the } \\
\text { profession of medicine in } \\
\text { general. }\end{array}$ \\
\hline 3 & $\begin{array}{l}\text { Doctor, is my } \\
\text { Teddy Bear Okay? } \\
\text { The "Teddy Bear } \\
\text { Hospital" as a } \\
\text { Method to Reduce } \\
\text { Children's Fear of } \\
\text { Hospitalization } \\
{[8]}\end{array}$ & Israel/ Palestine & 2008 & $\begin{array}{l}\text { Control group } \\
\text { study }\end{array}$ & $\begin{array}{l}\text { The children who } \\
\text { participated in the "Teddy } \\
\text { Bear Hospital" group } \\
\text { reported significantly lower } \\
\text { anxiety scores at follow-up } \\
\text { than the control group. Their } \\
\text { results suggest a way to } \\
\text { reduce children's anxiety } \\
\text { about hospitalization by } \\
\text { initiating a controlled, pain- } \\
\text { free encounter with the } \\
\text { medical environment in the } \\
\text { form of a "Teddy Bear } \\
\text { Hospital". }\end{array}$ \\
\hline 4 & $\begin{array}{l}\text { An Interactive Teddy } \\
\text { Bear Clinic Tour: } \\
\text { Teaching Veterinary } \\
\text { Students How to } \\
\text { Interact with Young } \\
\text { Children } \\
{[14]}\end{array}$ & Canada & 2017 & $\begin{array}{l}\text { Qualitative } \\
\text { research study }\end{array}$ & $\begin{array}{l}\text { The teddy bear clinic tour } \\
\text { supported positive behavior } \\
\text { in children and child- } \\
\text { friendly veterinary } \\
\text { vocabulary that helped } \\
\text { students achieve unique } \\
\text { communication between } \\
\text { them and the children who } \\
\text { participated. }\end{array}$ \\
\hline 5 & $\begin{array}{l}\text { Medical students' } \\
\text { experience of a } \\
\text { Teddy Bear } \\
\text { Hospital as part of } \\
\text { a pediatric } \\
\text { curriculum } \\
{[15]}\end{array}$ & Australia & 2018 & $\begin{array}{l}\text { Qualitative } \\
\text { observational } \\
\text { study }\end{array}$ & $\begin{array}{l}\text { The main factors identified } \\
\text { were student discomfort, } \\
\text { adapting communication to } \\
\text { the child's temperament and } \\
\text { developmental age, and the } \\
\text { influence of the Teddy Bear } \\
\text { Hospital context on } \\
\text { learning. For example, } \\
\text { students were uncomfortable } \\
\text { approaching families and } \\
\text { disclosing medical } \\
\text { information. Nevertheless, } \\
\text { they described it as an }\end{array}$ \\
\hline
\end{tabular}




\begin{tabular}{|c|c|c|c|c|c|}
\hline & & & & & $\begin{array}{l}\text { enjoyable learning } \\
\text { experience that taught them } \\
\text { to adapt communication to } \\
\text { the child. Students also } \\
\text { recognized that a hospital- } \\
\text { based event presents more } \\
\text { significant challenges than a } \\
\text { community-based event. }\end{array}$ \\
\hline 6 & $\begin{array}{l}\text { Teddy and I Get a } \\
\text { Check-Up: A Pilot } \\
\text { Educational } \\
\text { Intervention } \\
\text { Teaching Children } \\
\text { Coping Strategies } \\
\text { for Managing } \\
\text { Procedure-Related } \\
\text { Pain and Fear } \\
{[16]}\end{array}$ & Canada & 2015 & $\begin{array}{l}\text { Single-group, } \\
\text { pretest/posttest } \\
\text { design }\end{array}$ & $\begin{array}{l}\text { In this study, the results } \\
\text { suggest that an evidence- } \\
\text { based, interactive } \\
\text { educational program can } \\
\text { reduce young children's } \\
\text { anticipation of pain during } \\
\text { injection and help them } \\
\text { learn coping strategies. }\end{array}$ \\
\hline 7 & $\begin{array}{l}\text { The Teddy Bear } \\
\text { Hospital } \\
{[11]}\end{array}$ & Israel/Palestine & 2008 & $\begin{array}{l}\text { Qualitative } \\
\text { research study }\end{array}$ & $\begin{array}{l}\text { Because the border between } \\
\text { reality and imagination is } \\
\text { easily crossed in children, } \\
\text { results have shown that a } \\
\text { program conducted by } \\
\text { medical students to reduce } \\
\text { anxiety associated with } \\
\text { hospitalization using teddy } \\
\text { bears is very effective and } \\
\text { efficient. }\end{array}$ \\
\hline 8 & $\begin{array}{l}\text { Effectiveness of } \\
\text { pretend medical } \\
\text { play in improving } \\
\text { children's health } \\
\text { outcomes and well- } \\
\text { being: a systematic } \\
\text { review } \\
{[17]}\end{array}$ & Malaysia & 2021 & Scoping review & $\begin{array}{l}\text { Teddy bear hospital practice } \\
\text { has predominantly positive } \\
\text { outcomes, such as lower } \\
\text { anxiety levels and improved } \\
\text { health knowledge. However, } \\
\text { its effectiveness should be } \\
\text { tested in future studies using } \\
\text { more vigorous testing. }\end{array}$ \\
\hline 9 & $\begin{array}{l}\text { Healthcare } \\
\text { Professionals' } \\
\text { Views for the } \\
\text { Content of the } \\
\text { Teddy Bear } \\
\text { Hospital for a } \\
\text { Child Sexual Abuse } \\
\text { Prevention Module } \\
{[18]}\end{array}$ & Malaysia & 2021 & $\begin{array}{l}\text { Qualitative } \\
\text { research study }\end{array}$ & $\begin{array}{l}\text { Participants demonstrated } \\
\text { that using TBH as a } \\
\text { methodology is a good } \\
\text { approach for teaching CSA } \\
\text { prevention to preschool } \\
\text { children. }\end{array}$ \\
\hline 10 & $\begin{array}{l}\text { What do children } \\
\text { think about } \\
\text { doctors' } \\
\text { communication at } \\
\text { the Teddy Bear } \\
\text { Hospital? }\end{array}$ & Australia & 2021 & $\begin{array}{l}\text { ANOVA } \\
\text { (Analysis of } \\
\text { variance) }\end{array}$ & $\begin{array}{l}\text { The communication } \\
\text { described by the children at } \\
\text { TBH was overwhelmingly } \\
\text { positive, as they noted little } \\
\text { difference between medical } \\
\text { students and actual doctors. }\end{array}$ \\
\hline
\end{tabular}




\begin{tabular}{|c|c|c|c|c|c|}
\hline & [19] & & & & $\begin{array}{l}\text { However, medical students } \\
\text { need further evidence-based } \\
\text { training in communication } \\
\text { skills to improve their } \\
\text { ability to communicate with } \\
\text { very young children as they } \\
\text { couldn't comprehend the } \\
\text { medical information } \\
\text { disclosed to them. }\end{array}$ \\
\hline 11 & $\begin{array}{l}\text { Teddy Bear } \\
\text { Hospital - students' } \\
\text { learning in the } \\
\text { field of practice } \\
\text { with children } \\
{[12]}\end{array}$ & Norway & 2013 & $\begin{array}{l}\text { Qualitative } \\
\text { research study }\end{array}$ & $\begin{array}{l}\text { The students' experiences } \\
\text { and learning related to } \\
\text { communication/interaction } \\
\text { with children and that } \\
\text { students were attracted by } \\
\text { playing with the teddy bears, } \\
\text { Teddy Bear Hospital and } \\
\text { equipment. However, the } \\
\text { students' uniforms could } \\
\text { impact on children's } \\
\text { readiness in relation to } \\
\text { health services. }\end{array}$ \\
\hline
\end{tabular}

\section{Objectives and approaches taken in conducting the Teddy Bear Hospital}

It is evident that regardless of the different approaches and strategies used to implement the Teddy Bear Hospital, they all ultimately share the same intent: to raise health care awareness and alleviate young children's anxiety over medical treatment while focusing on the promotion of positive healthy lifestyle. Of the 11 included studies, 2 were quasi-experimental pre/post design [13], [16], 1 scoping systematic review[17], 2 were Analysis of variance ANOVA [7], [19], 1 control group trials[8] and the remainder were qualitative research studies[11], [12], [14], [15], [18].

The following studies have a particular group of people ranging from 20 to 543 participants that are aged between 4-12 years. All studies portray the teddy bear hospital as an intervention of medical roleplay. They took place place between the years 2008 to 2021, where two of the studies were in Canada (Ontario and London, ON)[14], [16], two in Malaysia[17], [18], two in Israel/ Palestine[8], [11], one in Norway[12], one in Germany[13], one in the Netherlands[7] and lastly, two in Australia[15], [19] as displayed in Figure 3, which predominantly involved either medical or veterinary students or researchers that dedicated their time and effort to improve on the effectiveness of medical roleplay through The Teddy Bear Hospital.

\section{Experience/outcomes with the respective objectives and approaches taken in conducting the Teddy Bear Hospital}

\section{Children's feelings after attending the teddy bear hospital}

The studies were thoroughly read and analyzed considering all aspects and showed different results. Six studies measured the children's emotional attitudes by examining the extent of their 
anxiety and fears about the illness and the hospital environment[11] as a part of their results and outcomes.

The first study on the effect of the teddy bear hospital as a method of treating preschool children's fear of future hospitalization was published by [8] as they studied 91 children in a case controlled examination which resulted in a significant decrease in anxiety scores related to hospitalization than the control group. One potential technique that might have encouraged the success of this study during the visit to the teddy bear hospital could be the supplement of simplified information by the medical students to the children about multiple complex procedures because as[20] states in his article on "Reducing medical fears in the general population of children" that the most feasible and desired way to eliminate the release of fear in children during medical encounters is by making use of interactive activities; for instance (The teddy bear hospital), because children during the ages of 4-8 begin developing their cognitive skills that can mostly be improved by engaging them in audiovisual and practical tasks.

\section{Children's behavior after attending the teddy bear hospital}

Children's medical experiences can have short- and long-term effects on their mental, physical, and emotional health [21]. Therefore, individuals such as [7], [16] have conducted various ANOVA based studies, one of which involved the distribution of questionnaires to children before and after visiting the Teddy Bear Hospital. After repeated measures, ANOVAs were used to analyze and examine the impact of $\mathrm{TBH}$ as a medical play intervention. The ANOVA study found more positive attitudes towards interacting with doctors and being sick, resulting in them being more attentive to the instructions they were given advised by. However, since it was one of their aims to deliver this event in a non-threatening manner, it is recommended to use pretend/toy medical equipment since going against that command might have a reverse reaction on the research[6].

\section{Children's healthcare awareness after attending the teddy bear hospital}

Two of the eleven studies included in this research paper focus on children's knowledge of health care. Both studies are based on qualitative research and concluded that after visiting the Teddy Bear Hospital, children have a significantly better idea of their body and its capabilities and its health and illnesses. In addition, it has been proven that preschoolers can learn better through the concept of medical role play. This directed medical play incorporates many of the essential elements of prepping and provides the opportunity to examine and manipulate medical equipment, process procedural information and acquire knowledge, all in a fun, non-threatening environment[6].

\section{Discussion}

This study was conducted to establish and analytically review the various implementations and techniques used to conduct the Teddy Bear Hospital. As we categorized our findings into three sections, the first was to identify and examine six of the eleven studies on children's feelings after visiting the teddy bear hospital, which again showed a positive result as this interactive activity helped to improve their connection with their fear of visiting the doctor 
and any type of health care, whether it was at a dental clinic or the emergency room at a hospital. However, based on our assessment, this review incorporates a comparatively small number of studies; most are qualitative observational research studies. This limitation may affect the hypothesis of the results for future executions.

What is unique about this review is that it demonstrates the potency of the concept of medical role play and the teddy bear hospital as a program to improve children's behavioral methods when encountering medical professionals. This is likely because playful activities are essential for children's development and learning, especially social interaction. Therefore, medical play helps them to open up to medical staff and the environment[22]. In general, since the studies presented in this review present population and sample bias in terms of the children participating in the teddy bear hospital, we can further explore a valuable alternative of running a teddy bear hospital specifically for neurodivergent children, as children with ASD are more likely to be hospitalized and usually have a higher tendency to get overly stimulated compared to neurotypical children[23], for instance, behaviors of children with severe ASD include: kicking, tantrums, property destruction, aggression, etc. In addition, specific effective strategies can help overcome their neurodiverse behavior, such as using calm language, communicating with pictures and visual cues, praise, and positive reinforcement [24]. Therefore, designing a teddy bear hospital to cater to their needs and requirements will get children with ASD more familiarized with hospital environments. Still, it also helps the health care workers equip themselves for challenges that lie in a professional medical career.

From the study results, it appears that the Teddy Bear Hospital helps reduce children's fear of hospitalization and promotes clarity and knowledge among participating children. Hence, they become more familiar with the medical procedures they may one day have to undergo. Furthermore, this method creates awareness of healthcare as it helps them understand the complexities of medicine in a simplified way [13]. In the future, more extensive research may aim to explore the imposed phobias of children in these situations, perhaps using an electroencephalogram (EEG) so that the teddy bear hospital program can be further modified locally to target these areas and more effectively to reduce children's fears and anxiety. In addition, one of the studies claims that some children were not as attentive during lectures or information as far as conveying medical information[21]. This only proves that the health care students who participate in this program should work on their communication skills, especially when it comes to verbalizing patient data to children aged 4-12 years old, as their mindset cannot yet comprehend the numerous ramifications lying within it [15].

\section{Conclusion}

The Teddy Bear Hospital intervention is undoubtedly a concept that helps to eliminate fear and anxiety that children go through when they enter a hospital environment of any kind. It acts as a stage of advancement for other beneficial elements such as improving childrens' attitude and behavior towards getting sick and seeing a doctor for treatment. It helps implementing healthcare awareness to help them become familiar with the medical field and its various perspectives from an early age. 


\section{References}

[1] D. Rao and I. Stupans, 'Exploring the potential of role play in higher education:

Development of a typology and teacher guidelines', Innov. Educ. Teach. Int., vol. 49, pp. 427-436, Oct. 2012, doi: 10.1080/14703297.2012.728879.

[2] U. Westrup and A. Planander, 'Role-play as a pedagogical method to prepare students for practice: the students' voice', Högre Utbild., vol. 3, no. 3, pp. 199-220, 2013.

[3] 'Joyce \& Weil (2000). Role Playing; Studying Social Behavior and Values. - Orest's Cogitarium'. https://kinasevych.ca/2009/02/19/joyce-studying-social-behavior-and-values/ (accessed Aug. 17, 2021).

[4] S. Shapiro and L. Leopold, 'A Critical Role for Role-Playing Pedagogy', TESL Can. J., vol. 29, p. 120, Aug. 2012, doi: 10.18806/tesl.v29i2.1104.

[5] '6089.pdf'. Accessed: Sep. 06, 2021. [Online]. Available: https://ler.letras.up.pt/uploads/ficheiros/6089.pdf

[6] E. R. Moore, K. Bennett, M. S. Dietrich, and N. Wells, 'The Effect of Directed Medical Play on Young Children's Pain and Distress during Burn Wound Care', J. Pediatr. Health Care Off. Publ. Natl. Assoc. Pediatr. Nurse Assoc. Pract., vol. 29, no. 3, pp. 265-273, 2015, doi: 10.1016/j.pedhc.2014.12.006.

[7] EDITOR, 'The Teddy Bear Hospital. How to influence the attitude of kindergarten children towards doctors, hospitals and falling ill', Eten Journal, Feb. 07, 2020.

https://etenjournal.com/2020/02/07/the-teddy-bear-hospital-how-to-influence-the-attitudeof-kindergarten-children-towards-doctors-hospitals-and-falling-ill/ (accessed Aug. 16, 2021).

[8] Y. H. Bloch and A. Toker, 'Doctor, is my teddy bear okay? The "Teddy Bear Hospital" as a method to reduce children's fear of hospitalization', Isr. Med. Assoc. J. IMAJ, vol. 10, no. 8-9, pp. 597-599, Sep. 2008.

[9] G. C. Baldivia, E. A. Neto, J. M. Aguiar, and G. Moreto, 'Bear Hospital Project as an Educational Strategy for the Development of Communication Skills During Medical Education', Arch. En Med. Fam., vol. 20, no. 2, pp. 49-58, Jul. 2018.

[10] M. Salmela, S. Salanterä, and E. T. Aronen, 'Coping with hospital-related fears: experiences of pre-school-aged children', J. Adv. Nurs., vol. 66, no. 6, pp. 1222-1231, 2010, doi: 10.1111/j.1365-2648.2010.05287.x.

[11] B. Porter, 'The teddy bear hospital', Isr. Med. Assoc. J. IMAJ, vol. 10, no. 8-9, pp. 646647, Sep. 2008.

[12] 'Teddy Bear Hospital - Students' Learning in the Field of Practice with Children Gjertrud Husøy, 2013'.

https://journals.sagepub.com/doi/abs/10.1177/010740831303300111 (accessed Aug. 21, 2021).

[13] 'Does the "Teddy Bear Hospital" enhance preschool children's knowledge? A pilot study with a pre/post-case control design in Germany - Corinna Leonhardt, Jutta MargrafStiksrud, Larissa Badners, Andrea Szerencsi, Rolf F Maier, 2014'. https://journals.sagepub.com/doi/abs/10.1177/1359105313488975?journalCode=hpqa (accessed Aug. 16, 2021). 
[14] J. S. Dalley, P. R. Creary, T. Durzi, and C. M. McMurtry, 'An Interactive Teddy Bear Clinic Tour: Teaching Veterinary Students How to Interact with Young Children', J. Vet. Med. Educ., vol. 44, no. 2, pp. 302-315, Summer 2017, doi: 10.3138/jvme.1115-180R1.

[15] L. Nheu, W. Uahwatanasakul, and A. Gray, 'Medical students' experience of a Teddy Bear Hospital as part of a paediatric curriculum', Focus Health Prof. Educ. Multi-Prof. J., vol. 19, no. 3, Art. no. 3, Nov. 2018, doi: 10.11157/fohpe.v19i3.217.

[16] J. S. Dalley and C. M. McMurtry, 'Teddy and I Get a Check-Up: A Pilot Educational Intervention Teaching Children Coping Strategies for Managing Procedure-Related Pain and Fear', Pain Res. Manag., vol. 2016, p. 4383967, 2016, doi: 10.1155/2016/4383967.

[17] A. A. Rashid, A. T. Cheong, R. Hisham, N. H. Shamsuddin, and D. Roslan, 'Effectiveness of pretend medical play in improving children's health outcomes and well-being: a systematic review', BMJ Open, vol. 11, no. 1, p. e041506, Jan. 2021, doi: 10.1136/bmjopen-2020-041506.

[18] A. A. Rashid, A. T. Cheong, N. H. Shamsuddin, D. Roslan, and R. Hisham Shunmugam, 'Healthcare Professionals' Views for the Content of the Teddy Bear Hospital for a Child Sexual Abuse Prevention Module', J. Child Sex. Abuse, vol. 30, no. 4, pp. 442-460, Jun. 2021, doi: 10.1080/10538712.2021.1890294.

[19] D. E. Moore, A. White, B. Jordan, and W. Uahwatanasakul, 'What do children think about doctors' communication at the Teddy Bear Hospital?', J. Paediatr. Child Health, Aug. 2021, doi: 10.1111/jpc.15688.

[20] P. D. Elkins and M. C. Roberts, 'Reducing medical fears in a general population of children: a comparison of three audiovisual modeling procedures', J. Pediatr. Psychol., vol. 10, no. 1, pp. 65-75, Mar. 1985, doi: 10.1093/jpepsy/10.1.65.

[21] T. Jaaniste, B. Hayes, and C. L. von Baeyer, 'Providing children with information about forthcoming medical procedures: A review and synthesis', Clin. Psychol. Sci. Pract., vol. 14, no. 2, pp. 124-143, 2007, doi: 10.1111/j.1468-2850.2007.00072.x.

[22] 'SciELO - Brazil - Therapeutic play: preparing the child for the vaccine Therapeutic play: preparing the child for the vaccine'.

https://www.scielo.br/j/eins/a/vMwFYYhftC8hH5Bjr75cSkQ/?lang=en (accessed Aug. 25, 2021).

[23] '[PDF] Children with autism spectrum disorder at a pediatric hospital: a systematic review of the literature. | Semantic Scholar'. https://www.semanticscholar.org/paper/Childrenwith-autism-spectrum-disorder-at-a-a-of-JohnsonRodriguez/7ec3b319d1336f6a4294e0bcd8a2039cefc4deff (accessed Aug. 25, 2021).

[24] 'Communication in autism spectrum disorder: a guide for pediatric nurses. | Semantic Scholar'. https://www.semanticscholar.org/paper/Communication-in-autism-spectrumdisorder\%3A-a-guide-Brown-Elder/4698f23120f080df9b638db1269ce23b26d2133c (accessed Aug. 25, 2021). 
